\title{
Deferral of currency variation losses as an earnings management tool
}

\author{
Ariovaldo dos Santos \\ USP - University of São Paulo \\ Edílson Paulo \\ USP - University of São Paulo
}

\begin{abstract}
Earnings management has become an important topic in accounting and finance in recent decades. This practice is possible due the existence of alternative accounting criteria for recognition, measurement and/or demonstration of earnings, creating opportunities for managers to choose one of the available options in order to reflect information in the desired form. This can sometimes distort the analysis of the company's performance. There are various ways to manipulate accounting information. This paper investigates whether there was earnings management in Brazil through deferral of losses due to exchange rate variations in 1999 and 2001, as well as through the respective amortization of these losses in following years. We analyze the companies that carried out such deferral in one or both years, and the respective amortization from 1999 to 2003, utilizing histograms and nonparametric methods, and find strong indications that the companies that chose such deferral did so to manage their earnings, in order to avoid showing decreased earnings or even losses.
\end{abstract}

Keywords: deferral, currency variation loss, earnings management.

Received in 08/12/2005; revised in 30/03/2006; accept in 20/04/2006.

\section{Corresponding authors:}

Ariovaldo dos Santos

Doutor em Controladoria e Contabilidade.

Universidade de São Paulo

Adress: Av. Prof. Luciano Gualberto, 908 - Prédo III,

Cidade Universitária, 05508900 - Sao Paulo, SP - Brasil

Email: arisanto@usp.br

Telephone: (11) 30915820
Edilson Paulo

Doutor em Controladoria e Contabilidade

Universidade Federal da Paraíba

Adress: Jardim Cidade Universitária, 58059900 - João Pessoa, PB -

Brasil Email: e.paulo@uol.com.br

Telephone: (83) 32167459

Editor's note: This paper was accepted by Alexsandro Broedel Lopes. 


\section{INTRODUCTION}

he information approach within accounting research has made an important $\mathrm{T}$ contribution in the past few decades (LOPES, 2002; LOPES and MARTINS; 2005). The works on accounting in the positive line of research under an opportunistic perspective formulate their hypotheses under the optic of WATTS and ZIMMERMAN; (1986):

a Incentive plan hypothesis - the assumption that the existence of conflicts of interest between agent and principal, based on the theory of contracts, can influence the quality of decisions and lead to attempts to maximize personal rather than company welfare. This fact leads to the formulation on incentive plans based on accounting information. Thus, executives can make opportunistic decisions on accounting procedures, seeking to meet desired targets that bear on their compensation.

b. Debt/equity hypothesis - the assumption that the higher the indebtedness quotient, the greater are the incentives for executives to choose accounting criteria that improve the company's performance. This practice is mainly observed when there are debt covenants that impose certain financial restrictions on the company.

c. Political cost hypothesis - the assumption that political considerations "induce political behavior in determined companies' choice of accounting procedures" (IUDICIBUS and LOPES; p.25). This means to say that the companies most watched by other agents tend of choose their accounting practices so as to transfer present profits to the future, reducing their political costs.

It is important to mention that the opportunistic perspective arises after the establishment of contractual mechanisms (ex post).

Various lines of positive research in accounting have gained space in the national and international literature. After the recent corporate scandals, the question of manipulation of accounting results has become more relevant. This manipulation has been given many names, the two most common being earnings management and creative accounting. Although the name may largely be a question of semantics, we feel that the second expression does not best describe the purpose here, because the use of the word "creative" may correspond more to improvement of accounting information than its manipulation (CARDOSO; 2004). According to Healy and Wahlen (1999, p. 368):

"Earnings management occurs when managers use judgment in financial reporting and in structuring transactions to alter financial reports to either mislead some stakeholders about the underlying economic performance of the company or to influence contractual outcomes that depend on reported accounting numbers"

The possibility of distorting accounting information normally originates from the existence of alternative criteria for recognition, measurement and/or demonstration within the accounting system, creating opportunities for administrators to choose one of the valid alternatives in order to depict information in the desired way and distorting the analysis of company performance. 
Deliberations 294/99, 404/01 and 409/01 from the Comissão de Valores Mobiliários (CVM, the Brazilian Securities Commission), allowed companies to defer losses resulting from extraordinary exchange rate variations in 1999 and 2001. This enabled some companies that suffered losses because of currency variations in these years to defer them and thus present more desirable accounting results.

Against this backdrop, the question analyzed by this article is as follows: Is there evidence of earnings management by the companies that deferred exchange rate losses, in such a way that it significantly changed their earnings results?

This question is addressed through an empirical study to verify whether the earnings alterations through deferral of currency variation losses by these companies were significant or not.

To answer this question, we conducted tests of hypotheses about the differences in the results, with and without deferral of exchange rate losses, in 1999 and 2001, as well as on the effects of the respective amortizations on earnings in subsequent years. To do this we employed histogram analysis and nonparametric tests. The accounting information was obtained from the database of the Institute for Accounting, Actuarial and Financial Research (Fipecafi), used in the company rankings of the magazine Melhores e Maiores ("Best and Biggest"), for the period 1999 to 2003. This information is limited to the largest 500 firms by turnover.

This work is an exploratory survey intended to obtain more concrete knowledge, incorporating characteristics not clearly explicit, as well as seeking to shed light on unknown dimensions (BEUREN, 2003) that need to be better understood. The empirical exercises are based on a bibliographical study of the theoretical references, to enable an analysis and interpretation of the existing scientific contributions on the theme, especially in books, theses, dissertations and articles, both national and international.

We do not discuss the theoretical questions on earnings management (manipulation of accounting information) and the main fundamentals and concepts of accountancy, or the accounting treatment to be adopted for such losses, since these themes have already been debated in various works (MARTINS, 2001; MARTINEZ, 2002; SZUSTER, 2002; SZUSTER and SZUSTER, 2003), besides being outside the scope of this study.

\section{DEFERRAL OF EXCHANGE RATE LOSSES}

Brazil suffered from years of high inflation until the Real Plan in 1994 finally stabilized the new currency, of the same name. At this point the Real was loosely tied to the dollar, in what financial analysts call a "sliding peg" regime, meaning the exchange rate was allowed to fluctuate within a narrow trading band that was gradually adjusted to reflect changes in relative currency values. However, by late 1998, Brazil's currency was considered by most analysts to be significantly overvalued and began to come under increasing pressure. After expending large sums of reserves to defend the Real, the government finally relented, and on January 13, 1999 the Brazilian Central Bank widened the trading band. But the market did not react positively, and in the following days the government decided to do away with the bands entirely and float Brazil's currency. The result was a steep devaluation against the dollar, which in January alone reached $64 \%$. The maximum quotation to buy dollars occurred on March 3, 1999, when the exchange rate was US\$1 = R 2.1639 (a devaluation of approximately 79\%), later strengthening to US\$ $=\mathrm{R} \$ 1.7212$ at the end of March, an accumulated devaluation of $42 \%$ in the first quarter. For the entire calendar year, the devaluation against the dollar was $48 \%$, while inflation was only $8.43 \%$ (according to the consumer price index).

BBR, Braz. Bus. Rev. (Eng. ed., Online), 
In this situation, the Brazilian Institute of Independent Auditors (IBRACON), until then called the Brazilian Institute of Accountants, issued Circular Letter 01 on January 20, 1999, emphasizing that the effects of the exchange rate variation caused by the maxidevaluation would not engender any type of adjustment in financial statements as at December 31, 1998, and recommended inclusion of explanatory notes, in this respect, following the orientation of International Accounting Standard 10 (IAS 10) issued by the International Accounting Standards Board (IASB).

Regarding the accounting treatment for 1999, the federal government issued Provisional Measure 1818 on March 25, 1999 (transformed into Law 9816/1999) ${ }^{1}$, permitting companies to defer any losses from the exchange rate variation.

To do this, companies could book, in a deferred asset account, the net negative result of the local currency value of obligations and credits in foreign currency because of the devaluation in the first quarter of 1999. This deferral then had to be amortized at a rate of at least $25 \%$ per calendar year as of that same year, 1999. This deferral was exclusively for purposes of the financial statements, because for calculation of income tax and social contribution on profit ${ }^{2}$, any exchange rate losses had to be fully recognized in the first quarter of 1999 (for firms using the real profit reporting method) or in the fiscal year (for those using annual calculation).

Nevertheless, IBRACON Technical Communiqué 02, of April 5, 1999, advised against the total or partial deferral of exchange rate variation, recommending that these should be recognized as revenues or expenses in the same period as they occurred. If a company chose deferral, IBRACON recommended that the auditor should issue the respective opinion with reservations about the financial statements for that period.

CVM Deliberation 294/1999 also permitted the exceptional procedure of postponing recognition of the negative net result of exchange rate changes in the first quarter of 1999 and established that these losses were to be amortized linearly in up to four years, as of 1999.

During the second half of 2001, there was another sharp devaluation of Brazil's currency, and once again the federal government, through Provisional Measure 03 of September 26. 2001 (converted into Law 10,305/2001), allowed companies (other than financial institutions) to carry out the same deferral. In 2001, the accumulated currency devaluation was $18.7 \%$, compared with inflation (consumer price index) of $9.44 \%$.

Seeing a need to regulate the question for publicly traded companies, the Securities Commission (CVM) issued Deliberation 404 on September 27, 2001, stipulating that the net result of exchange rate variation in 2001, whether negative or positive, should as a general rule pass through the statement of income for the year. However, exceptionally, it held that this net result, if negative, could be deferred and booked as a deferred asset, to be amortized in the following four years.

Then, on November 1 that year, the CVM amended this through Deliberation 404, ruling that such amortization would have to start that same year. In practical terms, this new ruling allowed deferring only $75 \%$ of the net exchange rate losses for 2001 .

\footnotetext{
${ }^{1}$ A provisional measure is an executive decree, with standing as ordinary law, that goes into effect immediately upon publication but is subject to subsequent approval or rejection by Congress. If approved, it is converted into a regular law.

${ }^{2}$ The Brazilian government raises revenue mainly through taxes per se and contributions, the difference being that the latter are earmarked for specific programs while the former go into the general fund (also subject to constitutionally mandated set-asides).
}

BBR, Braz. Bus. Rev. (Eng. ed., Online),

Vitória, v. 3, n. 1, Art. 2, p. 15-31, jan.-jun. 2006

www.bbronline.com.br 


\section{EARNINGS MANAGEMENT}

Despite all efforts to develop accounting techniques to reach the goals of offering better quality information that accurately depicts a company's situation, there is still situations were administrators try intentionally to distort the accounting reports to satisfy specific needs of the company or themselves. As stated earlier, the existence of multiple standards and criteria allows top managers to choose alternatives seeking to present financial statements to serve specific ends, hampering a fair analysis of company performance.

The disclosure of losses or earnings lower than expected by investors and analysts, among others, can bring undesirable effects, normally associated with eroded investor confidence. Furthermore, in many companies, executives' performance incentives (including compensation levels) are tied to accounting numbers. For this reason, there is always the possibility of managing the accounting results to avoid revealing poor performance, and there is a good deal of discretionary power to do so.

According to Fields, Lys and Vicent (2001), the accounting choices probably exist because it is simply impossible or impractical to eliminate them. This accounting flexibility also reduces the temptation of executives to obtain desired results through real decisions (presumably more expensive). Hence, the choice could be part of an optimal solution to the agency problem, even when it leads to no information.

There is no consensus among academics about the concept of earnings management. As mentioned earlier, Healy and Wahlen (1999, p. 368) consider it to occur when the executives use their discretionary judgment to manipulate the financial information to cast a better light on the company's performance. According to Santos and Grateron (2003; p. 11), earnings management refers to the application of accounting rules to manipulate, "the figures in the statements as judged most convenient."

According to Davidson, Stickney and Weil (1987), cited by Schipper (1989, p. 92), earnings management is the process of decisions taken, within the limits of accounting standards, to present the desired earnings level. In the same work, Schipper (p. 92) expands the scope of study, stressing that "disclosure management rather than earnings management, is "purposeful intervention in the external financial reporting process, with the intent of obtaining some private gains".

The accounting literature contains evidence that executives behave opportunistically in various situations. Szuster (2002, p.57) points to many reasons for companies to defer or not defer their currency variation losses, "but these are hard to define, since companies with similar characteristics adopt different alternatives." The option to defer such losses was not uniformly followed by companies, due to certain interests about the financial statements, which in part can be explained by the fact the devaluations of Brazil's currency might well have caused different impacts on companies' earnings and net equity, depending on their levels of exposure to currency value swings in either direction.

The empirical studies on earnings management present a set of incentives for the agent (administrator) to act opportunistically in choosing the criteria for measurement and/or demonstration of results, such as avoiding disclosure of losses or disappointing earnings (DECHOW, SLOAN and SWEENEY, 1995; BURSTAHLER and DICHEV, 1997; MARTINEZ, 2001, 2004; FUJI, 2004), increasing executive compensation (HEALY and WAHLEN, 1999; BARTOV and MOHANRAM, 2004), or minimizing the variability of errors in predicting earnings to shareholders (BARTOV, GIVOLY and HAYN, 2002; MARTINEZ, 2002). 
Among the incentives to manipulate accounting information that can have led some companies to defer currency variation losses are:

- Pressure from various economic agents for better earnings;

- The desire of executives to obtain higher compensation; and

- The need to meet the indicators or parameters established in loan contracts (debt covenants).

Some models have been developed to help the study of earnings management. Two of them are analysis of aggregate or specific accruals and histogram analysis. The analysis of accruals (aggregate and specific) is based on models depending on accrual basis accounting, which seeks to measure earnings in the economic sense, independently of the financial realization of transactions and events (DECHOW and DICHEW, 2002). These methods need to separate the accruals into:

- Discretionary accruals - which are artificial and whose object is only to manipulate the accounting numbers; and

- Nondiscretionary accruals - which are inherent to the company's activities.

So, the econometric models developed consider that discretionary accruals are a proxy for earnings management (HEALY, 1985; JONES, 1991, and KANG and SILVARAMAKRISHNAN, 1995). Although widely used in empirical research, the models based on accruals are criticized by some researchers, because they fail to distinguish between aggregate accruals resulting from changes in the economic climate and those from manipulation of accounting data (BENEISH, 2001). Hence, according to this argument, discretionary accruals are not good proxies for earnings management (BARTOV and MOHANRAM, 2004).

An alternative to the use of aggregate accruals is to use sector-specific accruals according to the company's activity, trying to verify which items are used for earnings management (MARTINEZ, 2001). The disadvantage of this disaggregated approach is the need for theoretical support based on the understanding of researchers and the analysis of how decision makers change the incentives associated with the accounting object under study. Besides this, its evidence is fragmented (FRANCIS, 2001).

Another approach is to use frequency distributions (histogram analysis) to verify abnormal behaviors around reference points such as zero earnings, previous year's earnings or expected earnings by financial analysts. The difficulty of this method is mainly in choosing the reference points, besides the fact they do not identify the magnitude of earnings management (MARTINEZ, 2001; TUKAMOTO, 2004).

The approach employed here is based on analysis of histograms, because it is one of the most commonly used in empirical studies on earnings management and it allows a broad vision of the practices of manipulation of accounting information.

\section{DATA ANALYSIS}

As said before, this work relies on the list of the 500 largest companies of the magazine Melhores e Maiores for 1999 and 2001. This ranking is based on annual turnover in U.S. dollars. From that list, 45 and 31 companies deferred currency variation losses in 1999 and 2001, respectively. Of these, 12 companies deferred such losses in both years, 33 only in 1999 and 19 only in 2001. Thus, from the sample utilized, 64 firms deferred exchange rate losses in 1999 or 2001, or both years. 
Of the 45 companies from 1999, 17 were publicly traded corporations (38\%), 19 limited liability companies (42\%), 6 closely held corporations (13\%) and 3 cooperatives (7\%). There were 9 firms in the food and beverage sector (21\%), 7 in the steel and metallurgy sector $(17 \%), 5$ in the electricity sector $(12 \%)$, and the others fell into diverse other sectors. In 2001 there were 45 listed corporations (48\%), 8 limited liability companies (26\%), and 8 closely held corporations (26\%), of which 8 were in the electric power sector (27\%), 7 in petrochemicals (24\%) and the other scattered in various other sectors.

To verify the normality of the variables used in this work, we applied the Kolmogorov-Smirnov (K-S) and Anderson-Darling (A-D) tests. According to these tests, the hypothesis of normality was rejected at a 0.05 significance level (p-value under 0.01 ), so we then employed nonparametric tests, which are more suitable for data that do not meet the presupposition of normality. The first hypothesis tested was whether there were significant differences in relation to the earnings of the companies with and without deferral.

$H_{1}=$ The returns on equity in 1999 with and without deferral are not significantly different.

The large nominal differences between the values for net earnings, and consequently, net equity of the companies analyzed, due to their size differences hampered the adequate use and interpretation of the data. Therefore, we used return on equity to check the influences of deferral on the earnings presented by the companies.

The Wilcoxon rank sum test (a nonparametric test) returned a p-value under 0.01 , so with a significance level of $0.05(\alpha=0.05)$. There are significant differences between the returns on equity with and without the effect of deferral of currency variation losses, in 1999. These differences can be observed in Graph 1, because the returns on net equity with the deferral effect have a greater number of companies with returns above zero compared with those that did not choose to defer. Besides this, there is a greater concentration of returns with deferral around the reference point (zero return), observed by the flattening (kurtosis) of the frequency distribution curves. 


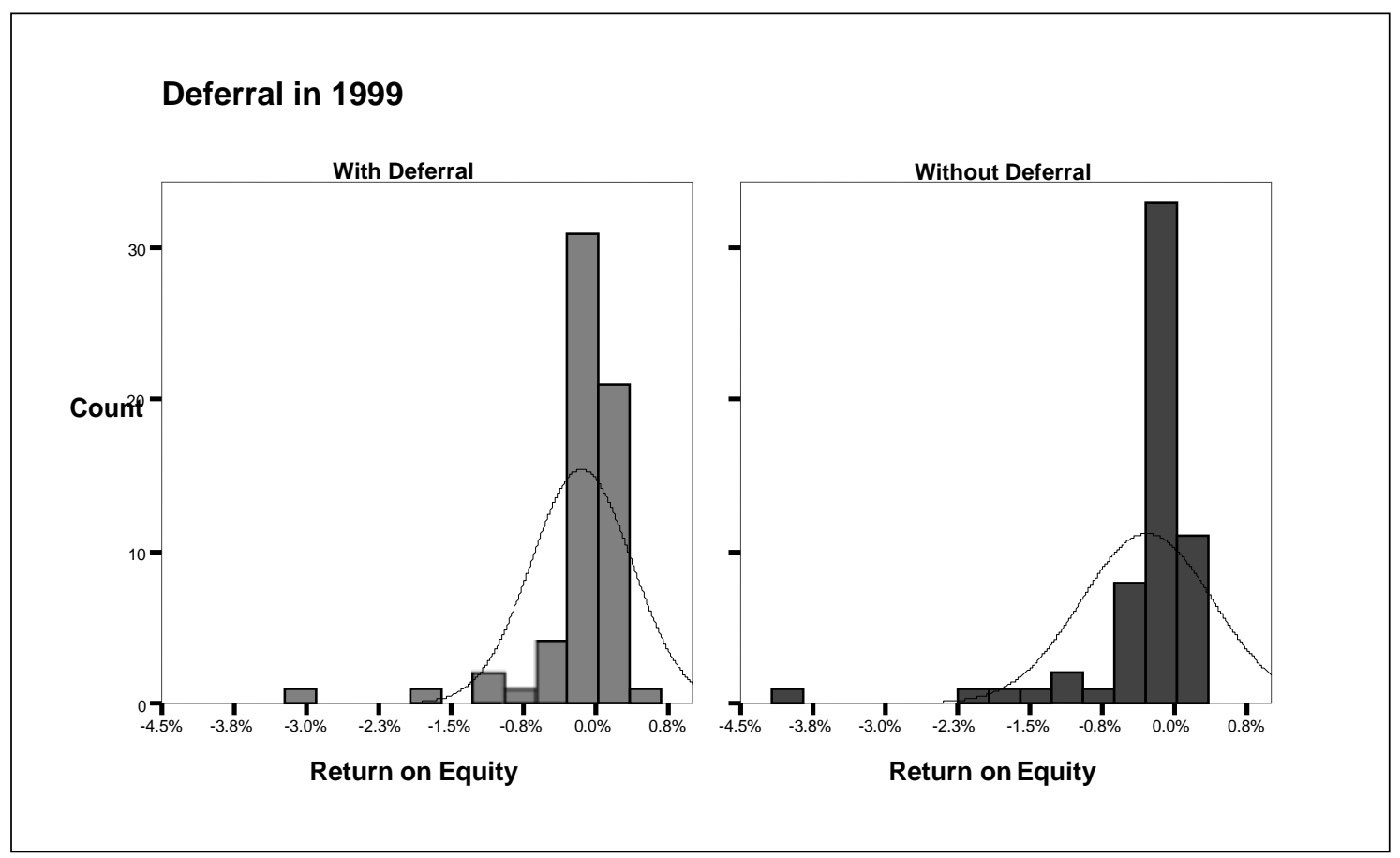

\section{Graph 1 - Comparison of the return on equity with and without the effects of deferral in 1999}

Tables 1 and 2 below show that if the deferral had not been done, $80 \%$ of the companies (that chose deferral) would have had negative earnings in 1999, and three of them would have had negative net equity. With the deferral option, the percentage of companies with negative earnings in the period fell to $53.3 \%$ and none had negative net equity. This agrees with Graph 1, which leads to the conclusion that there is evidence of earnings management through deferral of losses from exchange rate variations in this period.

Table 1 - Effect of deferral on net earnings in 1999

\begin{tabular}{l|c|c|c|c}
\hline \multirow{2}{*}{} & \multicolumn{2}{|c|}{ Without Deferral } & \multicolumn{2}{c}{ With Deferral } \\
\cline { 2 - 5 } & Frequency & $\%$ & Frequency & $\%$ \\
\hline Negative Earnings & 36 & $80.0 \%$ & 24 & $53.3 \%$ \\
Positive Earnings & 9 & $20.0 \%$ & 21 & $46.7 \%$ \\
\hline
\end{tabular}

Table 2 - Effect of deferral on net equity in 1999

\begin{tabular}{l|c|c|c|c}
\hline \multirow{2}{*}{} & \multicolumn{2}{|c|}{ Without Deferral } & \multicolumn{2}{c}{ With Deferral } \\
\cline { 2 - 5 } & Frequency & $\%$ & Frequency & $\%$ \\
\hline Negative Net Equity & 3 & $6.7 \%$ & & \\
Positive Net Equity & 42 & $93.3 \%$ & 45 & $100.0 \%$ \\
\hline
\end{tabular}

We conducted a new test (second hypothesis) to check whether there were any significant differences regarding the earnings of the companies with and without deferral in 2001, through return on equity.

$\mathrm{H}_{2}=$ The returns on equity in 2001 with and without deferral are significantly different. 
Using the same procedures as for 1999, we found that there is also evidence of earnings management through deferral of currency variation losses in 2001.

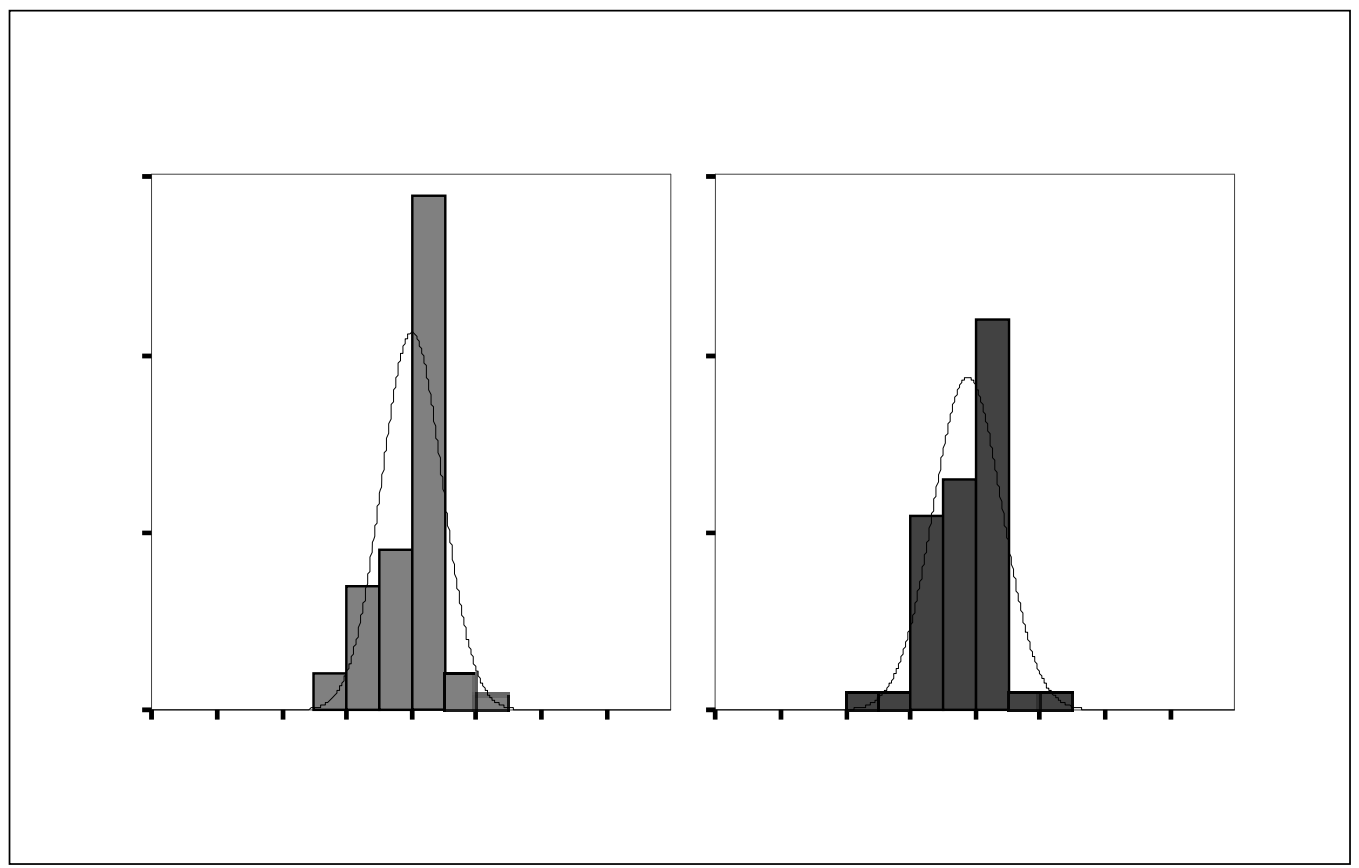

\section{Graph 2 - Comparison of the return on equity with and without the effects of deferral in 2001}

In Graph 2, return on equity with deferral, the results are more concentrated around the reference point (zero return) compared to those without deferral. This can be verified by the flattening of the frequency distribution curve, besides the presence of a larger number of companies with positive returns. Once again, the Wilcoxon test gave back a p-value less than 0.01 , and together with the graphical analysis, one can conclude that companies that deferred in 2001 were also significantly affected by this deferral.

Tables 3 and 4 below show that if they had not deferred the exchange rate losses, $71 \%$ of the companies would have had negative earnings in 2001, and 7 of these firms would have had negative net equity as well. The choice to defer made the percentage of negative earnings in the period fall to $42 \%$ and only 3 companies had negative net equity.

Table 3 - Effect of deferral on net earngings in 2001

\begin{tabular}{l|c|l|l|l}
\hline & \multicolumn{2}{|l|}{ Without Deferral } & \multicolumn{2}{l}{ With Deferral } \\
\cline { 2 - 5 } & Frequency & $\%$ & Frequency & $\%$ \\
\hline Negative Earnings & 22 & $71.0 \%$ & 13 & $41.9 \%$ \\
Positive Earnings & 9 & $29.0 \%$ & 18 & $58.1 \%$ \\
\hline
\end{tabular}


Table 4 - Effect of deferral on net equity in 2001

\begin{tabular}{l|c|c|c|c}
\hline \multirow{2}{*}{} & \multicolumn{2}{|c|}{ Without Deferral } & \multicolumn{2}{c}{ With Deferral } \\
\cline { 2 - 5 } & Frequency & $\%$ & Frequency & $\%$ \\
\hline Negative Net Equity & 7 & $22.6 \%$ & 3 & $9.7 \%$ \\
Positive Net Equity & 24 & $77.4 \%$ & 28 & $90.3 \%$ \\
\hline
\end{tabular}

Another question that can be raised derives from the results presented by the previous tests: if the companies deferred exchange rate losses in 1999 and 2001, seeking to avoid (or minimize) accounting losses, how did these same companies amortize the deferral in subsequent years? The amortization in both cases, according to legislation, was to calculate it linearly in up to 4 years, counted from the year of deferral. But this was not exactly the only criterion the companies actually used for the respective amortizations. Graphs 3 and 4 show what the companies really did.

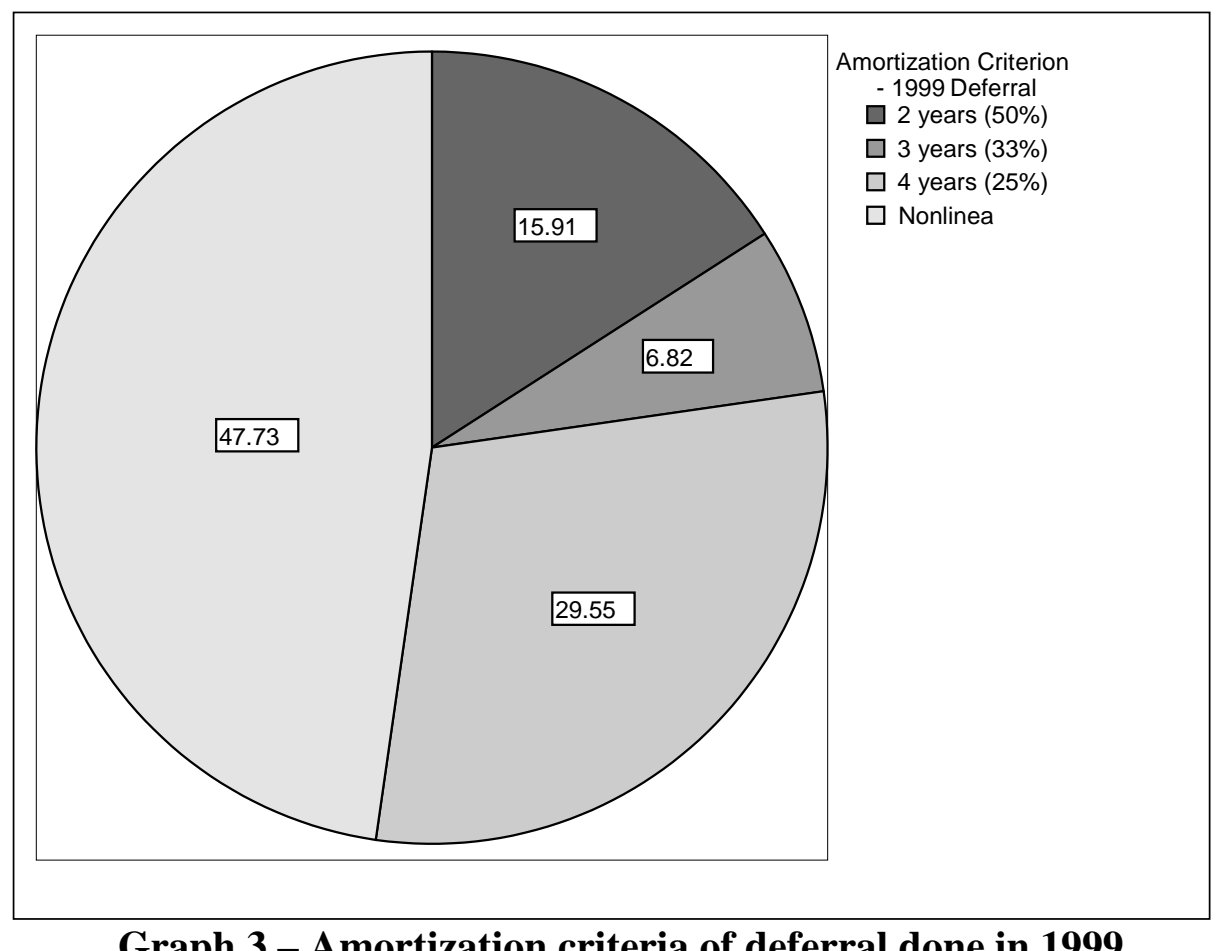

Graph 3 - Amortization criteria of deferral done in 1999

Graph 3 shows that only $29 \%$ of the companies that proceeded with the deferral in 1999 amortized the losses in the 4 years (25\% a year) according to established in legislation. But what stands out most is that $48 \%$ of the companies did not carry out linear amortization. 


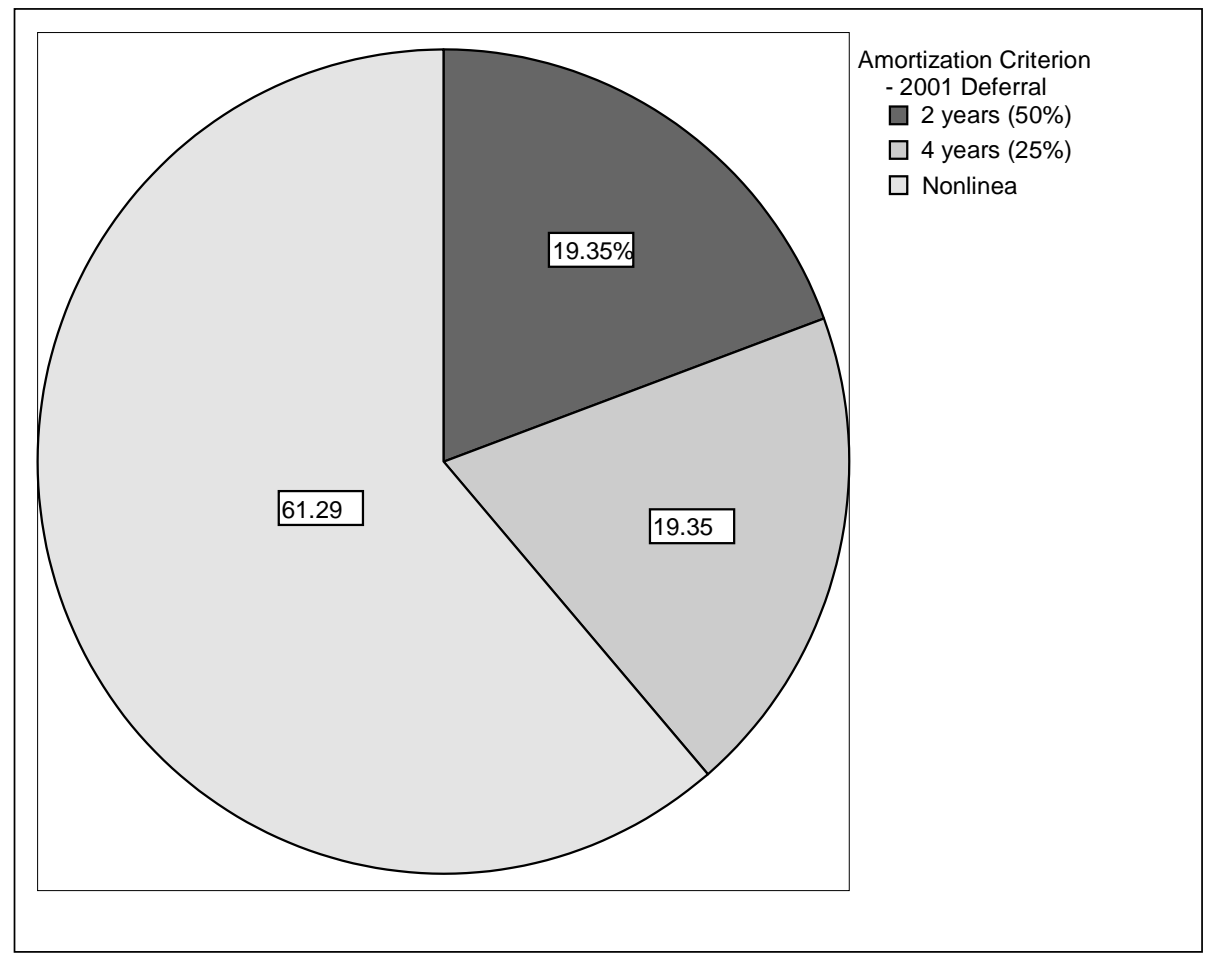

Graph 4 - Amortization criteria for deferral done in 2001

Once again, in 2001 there is evidence that at the time of amortizing the deferred exchange rate losses, $61 \%$ of the companies did not use the linear criterion (Graph 4). This finding implies examining a third hypothesis:

$H_{3}=$ The amortizations of the currency variation losses were used as a way to manage earnings by the companies.

To verify what motivated these companies to use nonlinear amortization during the period, we analyzed its influence on the respective earnings results through the returns in the years after the deferrals effected in 1999 and 2001.

Graph 5 (histogram) compares whether or not the companies were totally amortizing the exchange rate losses, according to a possible intention to present determined earnings results in 2000. Some of the companies that totally amortized their exchange rate losses by the end of 2000, as shown graphically below, presented approximately nil revenues with a certain normality in the frequency distribution. In contrast, the companies that did not totally amortize such losses by this year showed roughly zero earnings performance, but were totally dispersed over the frequency distribution. This fact leads to the conclusion that the adoption of different amortization criteria sought to avoid presenting negative accounting results or to reduce the variability of the results over the period, and that some firms did not have much chance to manage earnings because they had to recognize part of the exchange losses in the result for 2000 . 


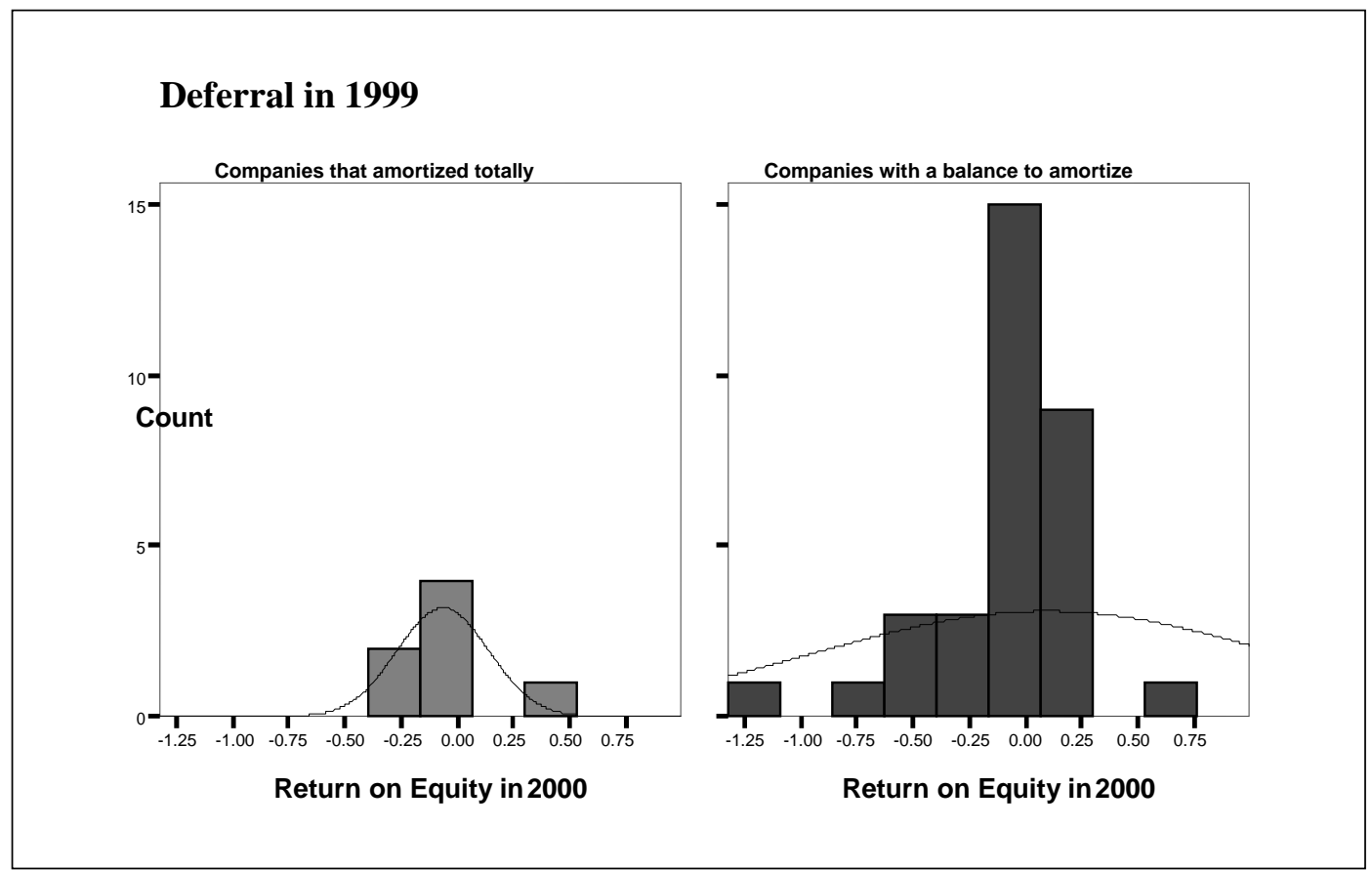

\section{Graph 5 - Comparison of the returns on net equity in 2000 - total or partial amortization}

Graph 6 reveals that some companies totally amortized by the end of 2001 the exchange rate losses from 1999 and other still had to amortize the remaining balance in 2002. Another finding is that the companies that deferred in 1999 and totally amortized the currency value losses by 2001 present a higher profitability concentration than the reference point (zero return), leading to the conclusion that they benefited from better results in the period to "unload" those losses and with this reduce the variability of their earnings over the period.

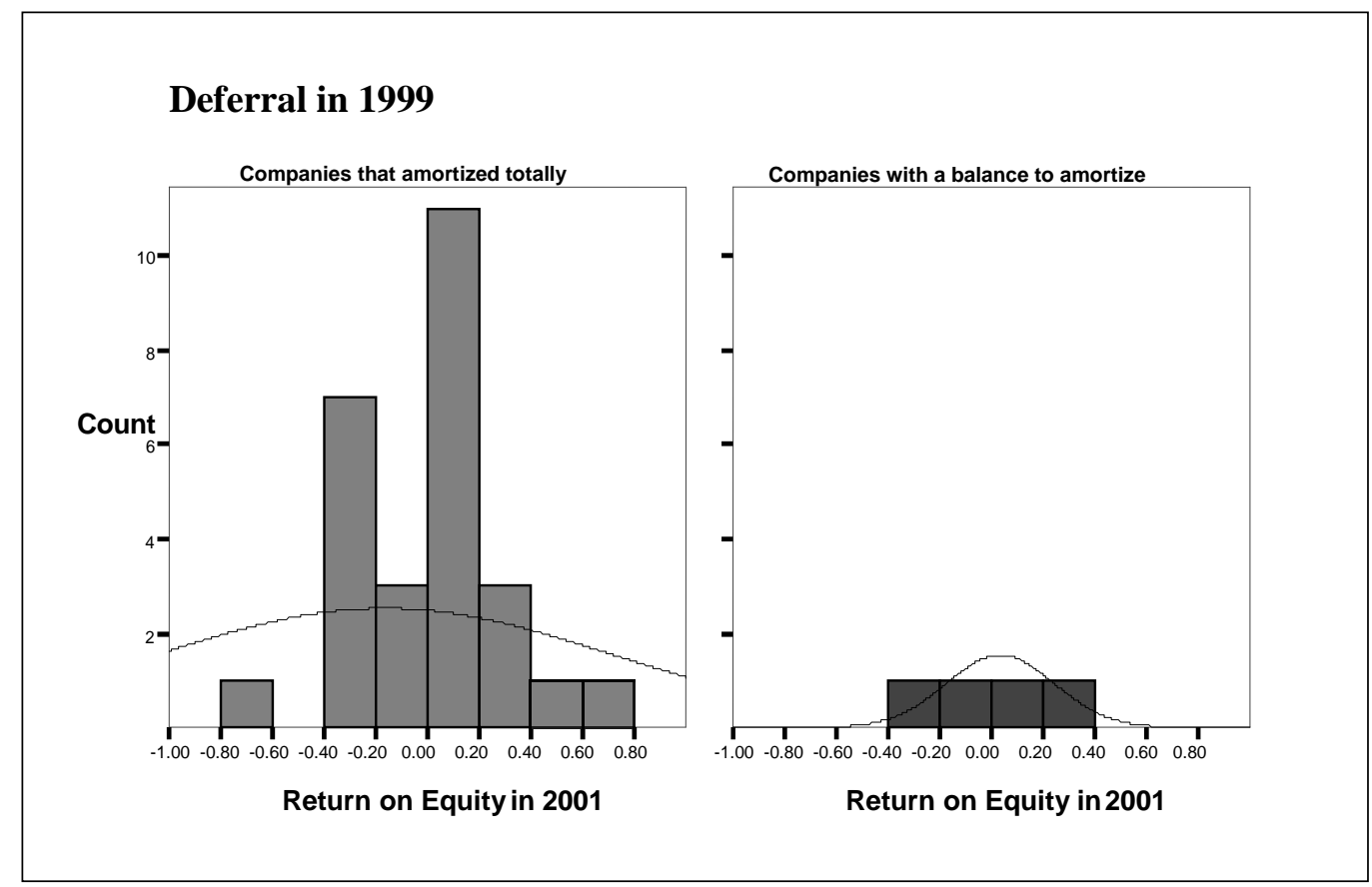

\section{Graph 6 - Comparison of the returns on net equity in 2001 - total of partial amortization}


However, regarding the amortization of currency variation losses in 2001, we found no behavior patterns, so there is no evidence of earnings management, as can be seen in Graphs 7 and 8.

\section{Deferral in 2001}

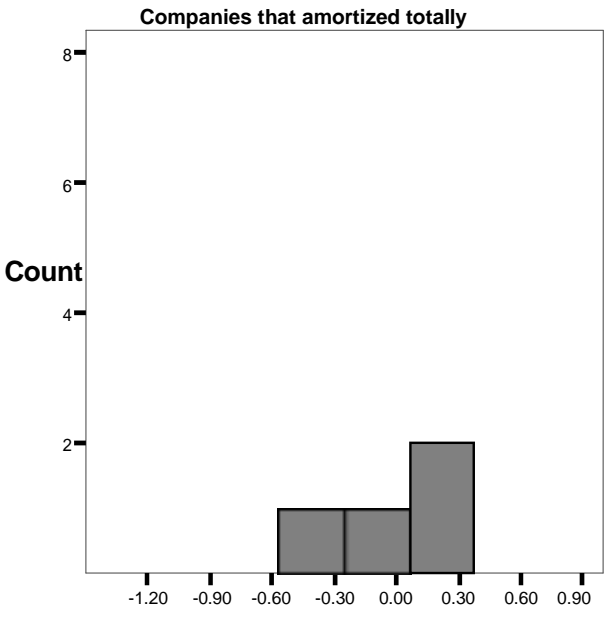

Return on Equity in 2002

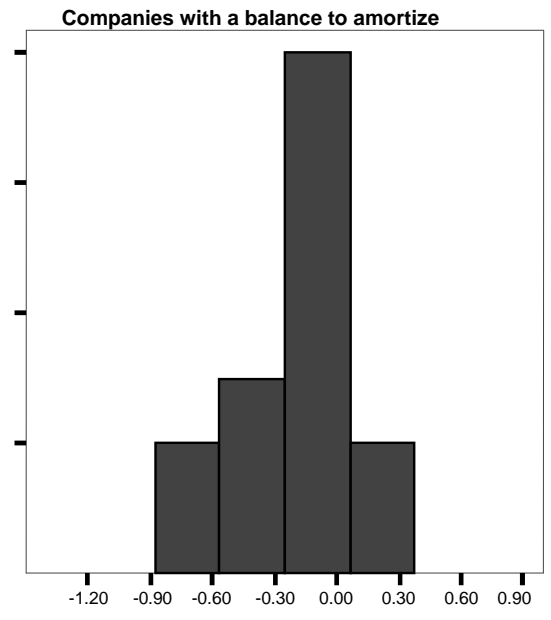

Return on Equity in 2002

Graph 7 - Comparison of the returns on net equity in 2002 - total or partial amortization

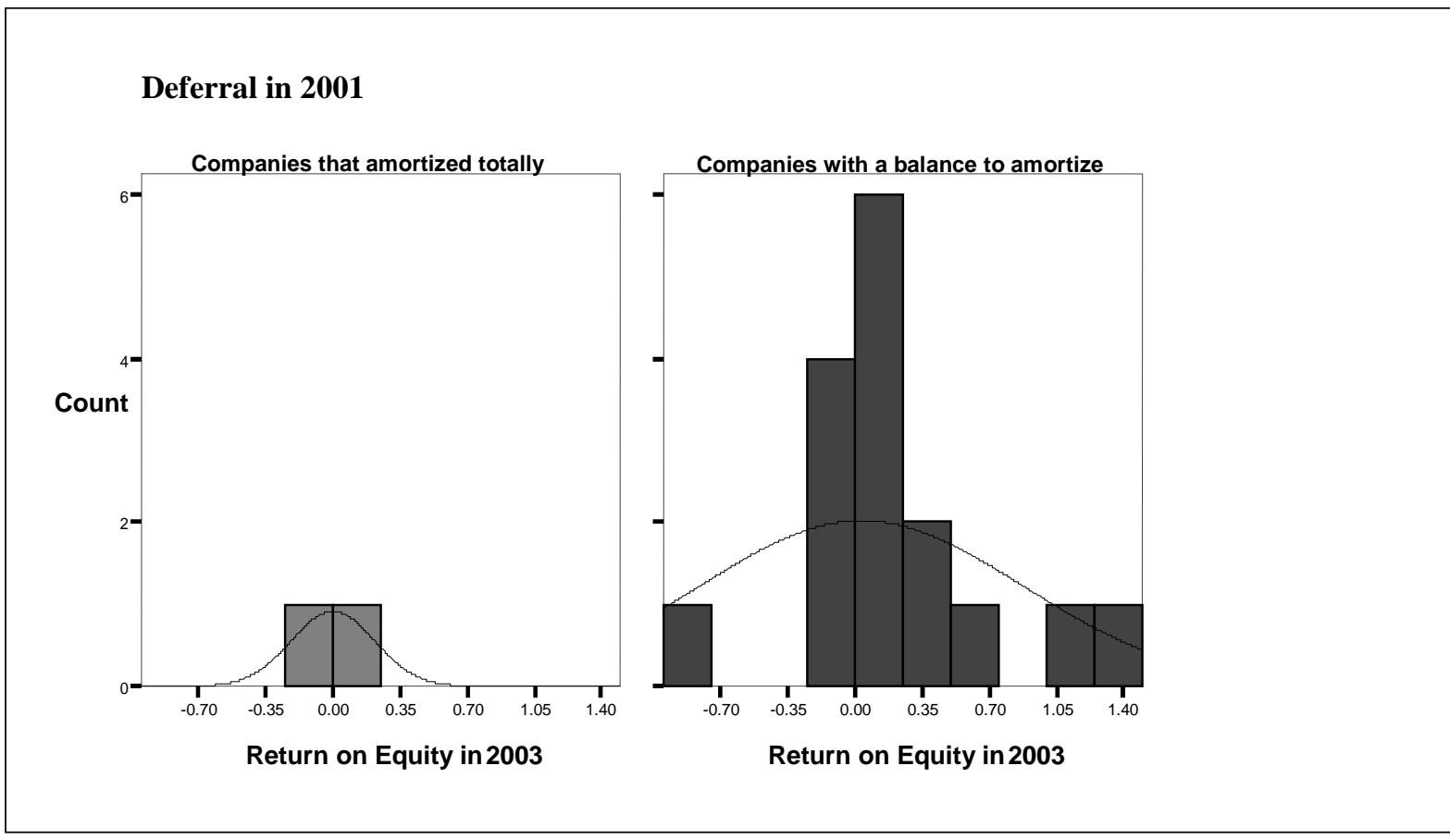

\section{Graph 8 - Comparison of the returns on net equity in 2003 - total or partial amortization}

Hunt et al (1996) and Abarbanell and Lehavy (2001), cited by Barton and Simko (2002, p.4), found that because of the natural reversal of discretionary accruals, the 
administrators who practice earnings management in a determined period are less able to repeat this in subsequent periods. In other words, if there are manipulations in a determined period to show satisfactory performance, normally in subsequent periods the difficulties to undertake similar operations are much greater. Dechow (1994) observes that part of the variation analyzed in the period by earnings management studies is expected by the reversal of the accruals of previous periods. It should be stressed that not every accrual is evidence of manipulation of accounting information. What must be examined is the atypical use of accruals, controlling for other economic and financial factors.

Another question (hypothesis 4) raised here was to check whether there was some relationship between the accounting results presented in 2001 between the companies that deferred in both 1999 and 2001 and those that did so only in 1999.

$\mathrm{H}_{4}=$ The companies that deferred only in 1999 presented more satisfactory results in 2001.

The majority of the companies that opted for deferral in 1999 managed to reverse the negative net earnings result by 2001, in relation to 1999 . If the effects were disregarded of the deferral in the two years, the number of companies presenting negative net earnings in 2001 would fall from 29 (in 1999) to 18 companies (Table 5), only considering those that chose to defer in 1999. Graph 9 shows that the profitability levels of the companies that chose to defer only in 1999 are more concentrated around a zero or a slightly negative return on equity.

Table 05 - Net earnings (without deferral) of companies in 1999

\begin{tabular}{l|c|c|c|c}
\hline & \multicolumn{2}{|c|}{ Net Earnings in 1999 } & \multicolumn{2}{c}{ Net Earnings in 2001 } \\
\cline { 2 - 5 } & Frequency & $\%$ & Frequency & $\%$ \\
\hline Negative Earnings & 29 & $87.9 \%$ & 18 & $54.5 \%$ \\
Positive Earnings & 4 & $12.1 \%$ & 15 & $45.5 \%$ \\
\hline
\end{tabular}

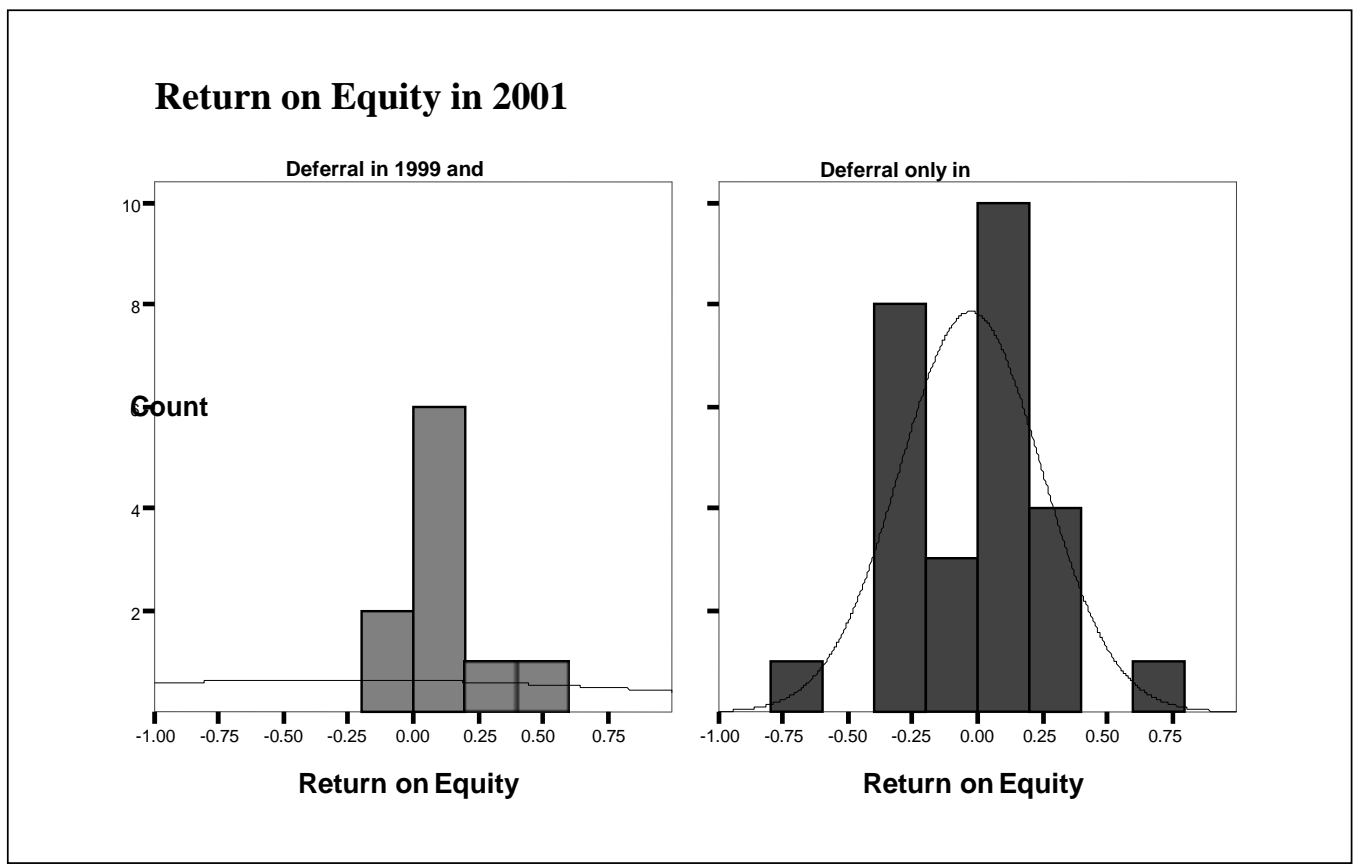

Graph 9 - Comparison of the returns on net equity in 2001 - companies that deferred in 1999 and 2001 and those that only deferred in 1999

BBR, Braz. Bus. Rev. (Eng. ed., Online), 
It must not be forgotten that part of the choice to defer losses from foreign exchange variations in 2001 can be attributed, initially, to the absence of similarly relevant impacts on the results for the period. While in 1999 the currency devaluation was $48 \%$, in 2001 it was only roughly $19 \%$. To this must be added the fact that inflation in 1999 was $8 \%$ and in 2001 it was $9 \%$.

\section{FINAL CONSIDERATIONS}

This work sought to find evidence of earnings management through manipulation of the losses caused by exchange rate variations in 1999 and 2001. Based on the tests of the hypotheses formulated, we found strong indications of earnings management by the companies that deferred these losses in 1999 and 2001. The option to defer aimed to reduce the variability of the accounting results, and mainly to avoid reporting negative earnings in these years. We also found that some companies, if they had not deferred these losses, would have presented negative net equity.

Even though the legislation issued by the accounting regulatory entities, mainly the CVM, indicates that the amortization of the losses was to be done linearly in up to four years, counted from the year of deferral itself, the majority of the companies analyzed did this nonlinearly. After analyzing the reflections of the loss amortizations on the results from 1999 to 2003, we found that failure to follow the linear amortization rule was due to the fact that the companies used the recognition of these losses in the result for the period according to their particular interest in showing economic performances.

We also found that part of the companies that chose to defer in 1999 did not do so again in 2001. It should be observed that the smaller currency devaluation this year and the presentation of positive results by the companies likely contributed to a large extent to the decision not to defer again.

Finally, to meet the objectives of this study, we presented evidence that for some companies the earnings management by deferring currency variation losses in 1999 and 2001 implied significant changes in their disclosure of accounting information.

\section{REFERENCES}

BARTON, Jan; SIMKO, Paul J. The balance sheet as an earnings management constraint. The Accounting Review. v. 77. Supplement 2002. pp.1-27.

BARTOV, Eli; GIVOLY, Dan; HAYN, Carla. The rewards to meeting or beating earnings expectations. Journal of Accounting and Economics. v. 33. n. 2. June 2002. pp.173-204.

; MOHANRAM, Partha. Private information, earnings manipulations, and executive stock-options exercises. The Accounting Review. v. 79. n. 4. 2004. pp. 88-920.

BRAZIL. Law 6404 (Law of Corporations): Brasília: DOU [Official Federal Gazette], 1976.

Law 9816.. Brasília: DOU, 1999.

Provisional Measure 1818. Brasília: DOU, 1999.

Law 10,305.. Brasília: DOU, 2001.

Provisional Measure 3. Brasília: DOU, 2001.

BENEISH, Messod D. Earnings management: a perspective. Managerial Finance. v. 27. n. 12. 2001. pp. 3-18.

BEUREN, Ilse Maria (org.). Como elaborar trabalhos monoGraphs em contabilidade: teoria e prática. São Paulo: Atlas, 2003.

BBR, Braz. Bus. Rev. (Eng. ed., Online),

Vitória, v. 3, n. 1, Art. 2, p. 15-31, jan.-jun. 2006

www.bbronline.com.br 
BURGSTAHLER, D., DICHEV, I. Earnings management to avoid earnings decrease and losses. Journal of Accounting and Economics. v. 24. n. 1. December 1997. pp. 99-126.

CARDOSO, Ricardo Lopes. Governança corporativa ou gerenciamento de resultados? Revista Brasileira de Contabilidade. n. 150. Nov.-Dec. 2004. pp. 18-37.

COMISSÃO DE VALORES MOBILIÁRIOS [Brazilian Securities Commission]. CVM Deliberation 294. Brasília: DOU, 1999.

CVM Deliberation 404. Brasília: DOU, 2001.

CVM Deliberation 409. Brasília: DOU, 2001.

DECHOW, P.M. Accounting earnings and cash flows as measures of firm performance: the role of accounting accruals. Journal of Accounting and Economics. v. 18, n. 1. 1994. pp. 342.

; DICHEV, I. D. The quality of accruals and earnings: the role of accrual estimation errors. The Accounting Review. v. 77. Supplement 2002. pp. 35-59.

; SLOAN, R.G.; SWEENEY, A. P. Detecting earnings management. The Accounting Review. v. 70, n. 2, April 1995. pp. 193-225.

FIELDS, Thomas D..; LYS, Thomas Z.; VICENT, Linda. Empirical research on accounting choice. Journal of Accounting and Economics. v. 31. 2001. pp. 255-307.

FRANCIS, Jennifer. Discussion of empirical research on accounting choice. Journal of Accounting and Economics. v. 31. 2001. pp. 309-319.

FUJI, A. H. Gerenciamento dos resultados contábeis no âmbito das instituições financeiras atuantes no Brasil. Master's Dissertation. São Paulo: FEA-USP, 2004.

HEALY, Paul M. The effect of bonus schemes of accounting decisions. Journal of Accounting and Economics. v. 7. April 1985. pp. 85-107.

;WAHLEN, James M. A review of the earnings management literature and its implications for standard setting. Accounting Horizons. v. 13. n. 4. Dec. 1999: pp. 365-383.

Instituto dos Auditores Independentes do Brasil - IBRACON. Circular Letter 01. Brazil: 1999

. Technical Communiqué 02. Brazil: 1999.

INTERNATIONAL ACCOUNTING STANDARDS BOARD - IASB. Normas Internacionais de Contabilidade 2001. São Paulo: IBRACON, 2002.

IUDÍCIBUS, Sérgio de; LOPES, Alexandro B. Teoria avançada da contabilidade. São Paulo: Atlas, 2004.

JONES, Jeniffer J.. Earnings management during import relief investigations. Journal of Accounting Research. v. 29. n. 2. Autumn 1991. pp.193-228.

KANG, Sok-Hyon.; SIVARAMAKRISHAMAN, K. Issues in testing earnings management: an instrumental variable approach. Journal of Accounting Research. v. 33. n. 2. Autumn 1995. pp. 353-367.

LOPES, Alexandro B. A informação contábil e o mercado de capitais. São Paulo: Atlas, 2002. Atlas, 2005.

; MARTINS, Eliseu. Teoria da contabilidade: uma nova abordagem. São Paulo:

MARTINEZ, Antônio Lopo. Gerenciamento dos resultados contábeis: estudo empírico das companhias abertas brasileiras. Doctoral Thesis. São Paulo: FEA-USP, 2001. 
. Detectando earnings management no Brasil: estimando as acumulações discricionárias. Anais do IV Congresso USP de Controladoria e Contabilidade. 2004. São Paulo, 2004. CD-ROM.

MARTINS, Eliseu. Contabilidade versus fluxo de caixa. Caderno de Estudos da Fipecafi. São Paulo: Fipecafi, Jan.-April 1999, n. 20, pp. 1-10.

. Variações Cambiais: Contabilidade e Fisco. Boletim IOB Temática e Balanços. São Paulo: IOB, 2001, n. 8, pp. 1-5.

SANTOS, A., GRATERON, I. R. G. Contabilidade criativa e responsabilidade dos auditores. Revista Contabilidade \& Finanças - USP. n. 32. May-Aug. 2003. pp. 7-22.

SCHIPPER, Katherine. Commentary on earnings management. Accounting Horizons. v. 3. n. 4. Dec. 1989: pp. 91-102.

SZUSTER, Fortunée R. Comportamento do mercado de ações frente ao diferimento cambial de março de 1999: um estudo exploratório. Master's Dissertation. Rio de Janeiro: Universidade do Estado do Rio de Janeiro, 2002.

SZUSTER, Fortunee; SZUSTER, Natan. Tratamento contábil do câmbio flutuante: uma proposta frente à grande volatilidade. Boletim IOB Temática Contábil e Balanços, São Paulo: IOB, 2003, n. 8, pp. 1-6.

TUKAMOTO, Yhurika S. Contribuição ao estudo do "gerenciamento" de resultados: uma comparação entre as companhias abertas brasileiras emissoras de ADRs. Dissertação (Mestrado). São Paulo: FEA-USP, 2004.

WATTS, Steed L.; ZIMMERMAN, Jerold L. Positive accounting theory. New Jerjsey: Phentice-Hall, 1986. 